\title{
THE IMPACT OF OPPORTUNITY MANAGEMENT ON THE RELATIONSHIP BUSINESS MODEL (A STUDY IN THE POLSH HOUSING INDUSTRY)
}

\section{Bartosz Deszczyński}

Poznan University of Economics and Business, Poland

\begin{abstract}
This paper illustrates the level of proficiency of multistage and multi-channel dialogue between the customers and the companies on the example of opportunity management conducted primarily in the Polish housing industry. Opportunity management (also called lead management) is an initial customer relationship management (CRM) process that connects the sales persons and the customers ready to make a purchase. Unlike the other processes its close link to transaction makes it ideal to achieve quick-wins making CRM business case cogent. However the research shows that the companies have severe problems in sustaining coherent dialogue with their prospective buyers what possibly reflects their relationship management immaturity. The aim of this article is to explain the nature of this phenomenon and its impact on the relationship business model.
\end{abstract}

Keywords: Customer relationship management, Housing industry, Lead management, Multi-channel dialogue, Opportunity management, Poland

DOI: http://dx.doi.org/10.15549/jeecar.v3i2.137

\section{INTRODUCTION}

Opportunity management is an acquisition process also known as lead management aimed in systematic registration and processing of information about customer interest in company offer (Baran \& Galka, 2013; Deszczyński, 2013). It is usually classified as initial customer relationship management (CRM) process or sub-process, which facilitates sharing customer insights from nontransactional to transactional points of contact (Kotarba, 2016; Deszczyński, 2005). Unlike more long-term oriented CRM processes as loyalty management or anti-churn management, opportunity management offers a close link between customer care and the calculable financial results. Hence one can propose a thesis that proficiency in dealing with the leads can act as an indicator of the overall corporate relationship management maturity.

The article presents the findings of multistage and multi-channel mystery client research conducted in the Polish housing industry. The results are also confronted with earlier research conducted in automotive and tourist industry. In contrast to the other commercial studies, in this research not only initial response time and overall success rate was investigated, but performance of the whole process starting from the first online enquiry to personal and follow-up contacts.

\section{THE THEORETICAL FRAMEWORK}

The essence of opportunity management is to 
provide prospective buyers (loyal and new customers) with useful information and solutions in the right place and at the right time. It can take form of a prompt reaction to the submitted requests or a proactive proposal based on processed customer knowledge. Even if traditionally so called hot leads (customers determined to buy immediately) were perceived as most valuable (Sauberlich, Smith \& Yuhn, 2005), opportunity management has to be perceived in broader perspective, as an initial CRM process (Bueren, Schierholz, Kolbe \& Brenner, 2005; Rigby $\&$ Ledingham, 2004). In this context opportunity management can be also defined as consolidation, qualification and prioritization of contacts with the prospective buyers (Salomann, Dous, Kolbe \& Brenner, 2006).

The effectiveness of opportunity management relies heavily on cooperation between different groups of employees: the customer contact center teams, sales force and the marketing teams. Servicing customer enquiries, generating, scoring and qualifying leads and finally managing the sales process requires sustaining professional online dialogue without any discontinuities between various communication channels. This is of crucial importance, because according to contemporary media multiplexity theory, the multimodality - the use of multiple media, is positively linked with the relationship's strength or so called level of interdependence (Ledbetter \& Mazer, 2014; Haythornthwaite et al., 2007). Hence a wellorganized lead management process will transfer the customer from the initial point of contact to the stage where his needs can be addressed (McGinnis \& McCarty, 1998).

Supporting dialogue requires integrated, gradual customer data build-on and seamless information sharing in a group of customer facing personnel (Payne \& Frow, 2013). Data integration is usually supported by an appropriate ICT tool (especially in the bigger organizations), but the human factor seems to be the most decisive one, especially at the cut-points of the online and offline communication channels. Therefore even connecting every point of contact to an integrated ICT system does not guarantee that knowledge which was obtained in the initial stages of the dialogue will be properly utilized later on.

The ability to deliver services in an convenient way requires empowering employees at every point it is reasonable to do so. It can be e.g. the authority to negotiate with the customer instead of handing ready-made brochures and offers only or simply time-accurate access to information (Deszczyński, 2016). This seems to go in line with the trends in the customer expectations to cocreate the value as described in Prahalad's and Ramaswamy's DART model (Mazur \& Zaborek, 2014; Prahalad \& Ramaswamy, 2004). Only contacts with the company which offer personal high utility will add value reinforcing the relationship. "Each time you do something for me, do it better than the last time" (Gordon, 2013, pp. 37-38). If it is not the case, customer will not take the time to share more information on his specific needs. In turn the organization loses control over the way customer goes from information collecting phase to buying decision.

\section{THE METHODOLOGY OF THE RESEARCH}

The theoretical discussion on effective multichannel opportunity management process is confronted in this article with the results of a research carried out in the Polish housing industry. The housing industry was chosen deliberately as an example of a contractual business with high level of customer engagement and openness to dialogue with the companies. It is no wonder since buying a house or a flat involves considerable financial resources and occurs only a few times in a lifetime, as in Europe in average people change the place of residence once in 15 years) (The Independent, 2016; Miesięcznik Administrator, 2014).

All research activities were conducted in March and April 2016 in several steps. The research sample consisted of 22 housing developers from Poznań (Poland) representing more than $50 \%$ of housing investment in the area (Domiporta, 2016). Forty mystery clients were asked to initiate dialogue with up to three companies. To ensure the objectivity of research each developer was contacted by at least five mystery clients what brought a sample of 126 sales processes. The contacts were continued through the different channels: online, hotline and personal (showroom / investment location visit). Such sequence of contacts reflects behaviour of the contemporary customers, as 33\%to 53\%of them use web pages of 
the developers as source of information and internet in general (e.g. web pages of real estate agents or online comparison services) is the main search tool (Wielgo, 2015; Polińska \& Skoczeń, 2014). In addition follow-up contacts after personal contact were also examined (provided that the company representative contacted the client in maximum three working days after the direct contact took place).

The mystery clients were asked to give their contact data freely. In addition they were to express the same needs during the two initial stages of the process (online and hotline) so that the servicing person could make a potential use of them in a personal contact, provided his company managed to register and process this information. The research participants were asking both simple and advanced questions. The first ones concentrated on the price and other terms and conditions of the offer with the special emphasis on how their needs definition was transferred into the offer. The latter ones dealt with the state program supporting the purchase of the first flat by the young couples and were designed to examine how the front office personnel cooperates with the back office in order to deliver the information customer required.

The research participants were given the exact guidelines on what is considered a quality answer or desired behaviour of the personnel of the developers. Since every process involving humans is always subjective and the absolute quality does not exist (Deszczyński, 2011), the mystery clients could also assess the overall feeling of the particular encounter. Both methods were equally considered in the final aggregated assessment.

The additional research stage was focused on so called long-term lead management, which can be described as the ability of the company to process the information provided by the prospective buyer and exploit its potential in the possible best moment. In this research it was a single customer contact looking for a fast purchase, however conditioned by particular circumstances which were postponing the decision for a month. In the ideal situation the goal was to ask customer for contact data and register it with a task for renewed contact in the specified time.

\section{THE RESEARCH RESULTS}

As al ready indicated, the main research scenario involved three stages of contacts: online, hotline and personal, supplemented by the follow-up contacts. The online contacts were usually preceding all the other unless the company managed to contact the customer by phone using the "fast contact box". The results presented in Fig. 1 show, that the general performance in online communication is poor. Only $18 \%$ of the companies offered and managed to effectively use the instant contact tool and responded to initial enquiry in less than an hour. The content of the answers was disappointing and reactive what can be best observed in the case of cross-sell and up-sell options. The overall impression reflects the average level of performance. 


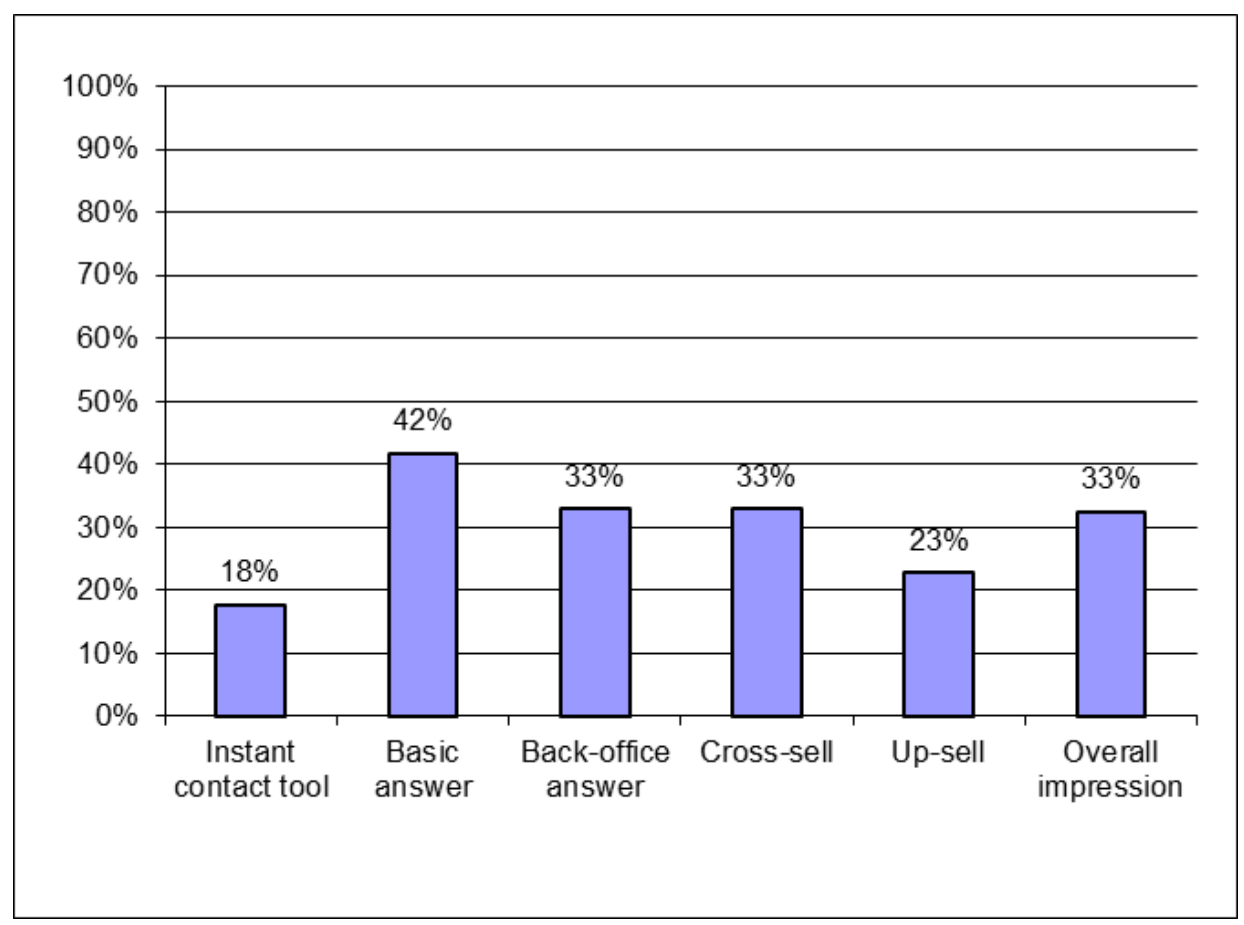

Figure 1. Opportunity management in online channel.

Source: Own work

During the hotline contacts companies had for the first time a chance to identify the customer upon the information posted in an online enquiry. In order to make it easier for their interlocutors, the mystery clients were asked to intimate they had contacted the company before on the same purpose. Unfortunately, as the Fig. 2 reveals, only one third of the companies took a chance to provide exceptional quality of an uninterrupted dialogue. None the less the overall impression was better by approximately $20 \%$ than after the online contact.

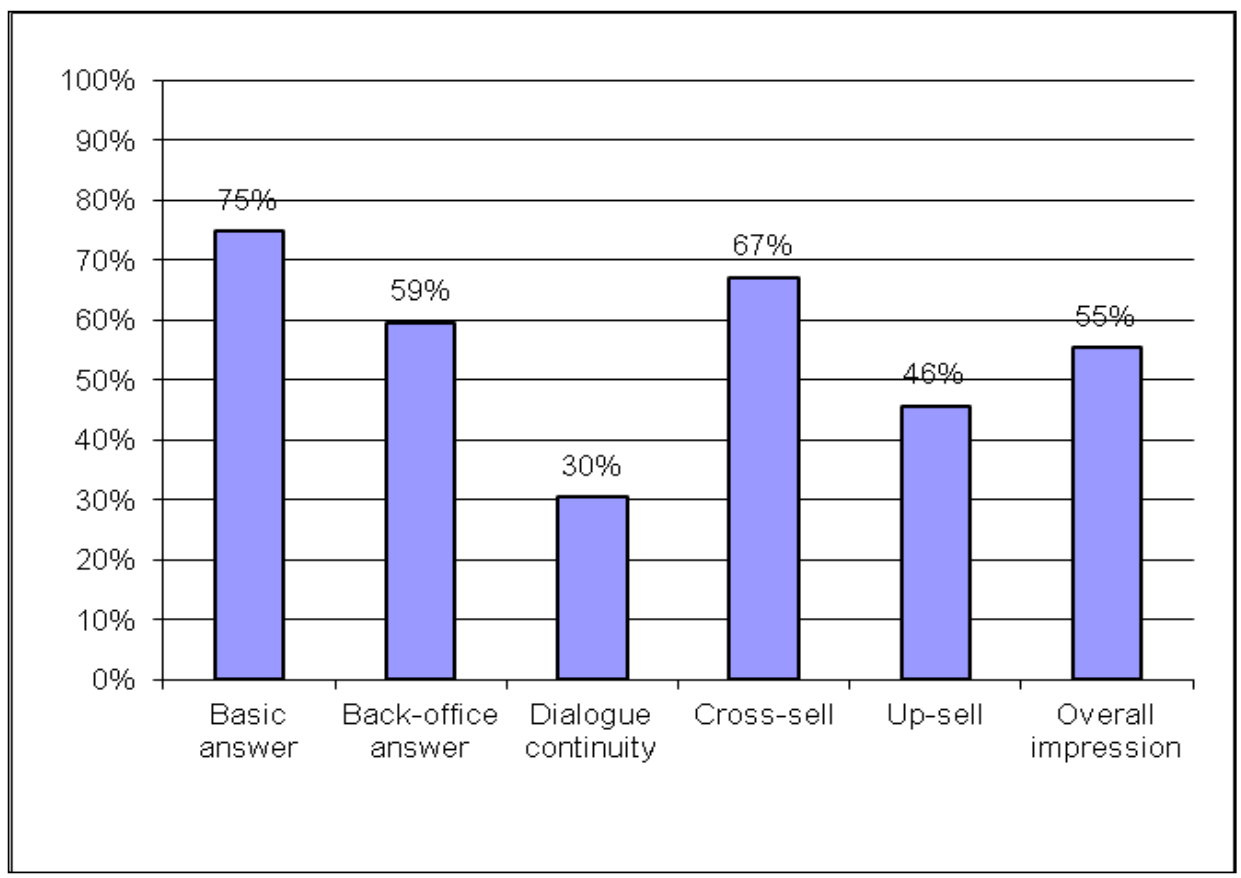

Figure 2. Opportunity management in hotline channel.

Source: Own work 
The personal encounter traditionally offers the best chance for interacting with the customer and thus enhancing high quality dialogue (Deszczyński $\&$ Mielcarek, 2015). And so in this research it has also proved to be the best method for winning the customers. The companies scored particularly well in terms of dialogue continuity (see Fig. 3).
However the overall difference between hotline and direct channel is rather insignificant, especially given the disparate financial effort needed to provide hotline services and direct contact possibility. The untapped potential for individual customer care was particularly visible in the unwillingness to prepare written offers.

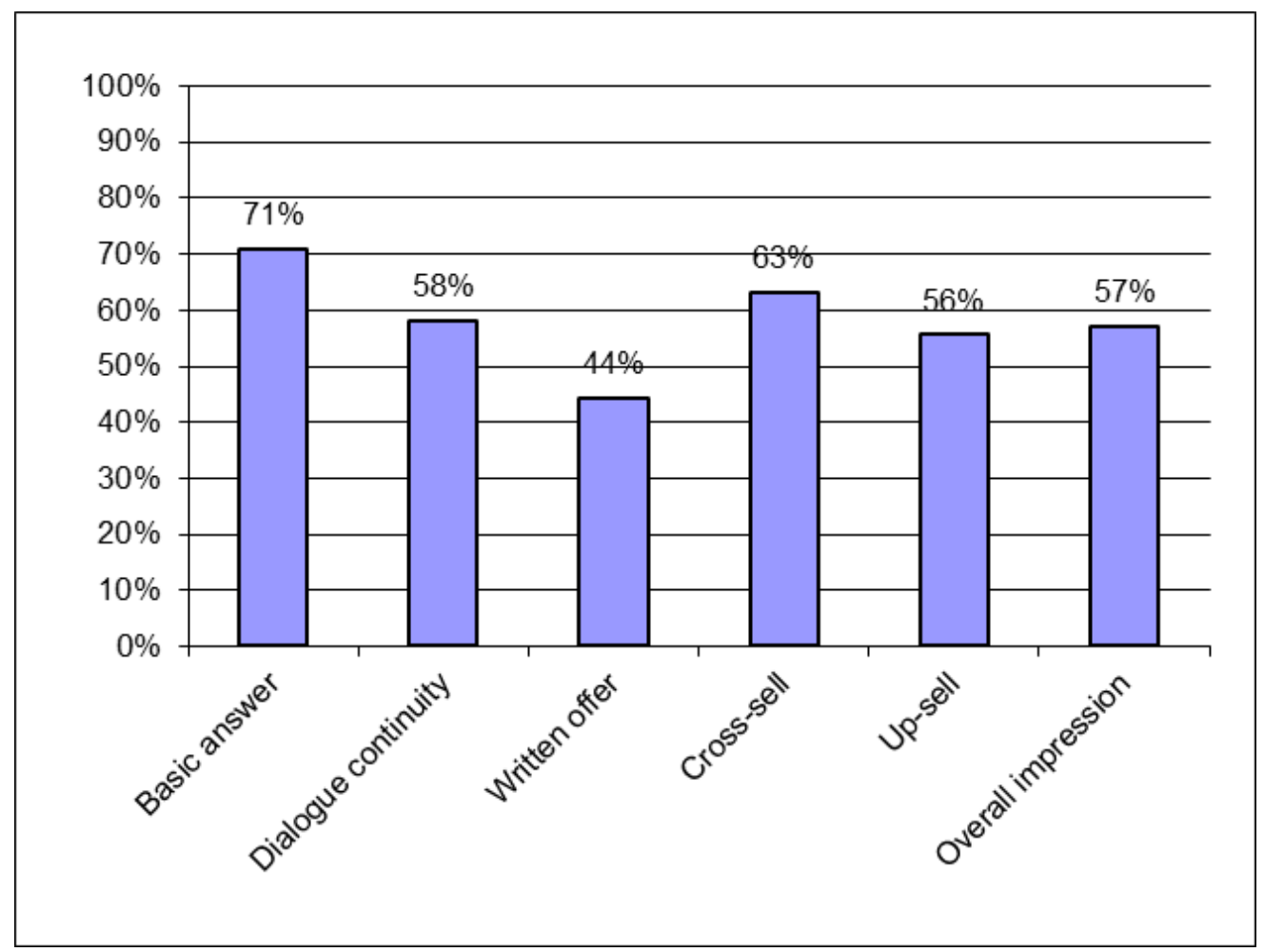

Figure 3. Opportunity management in personal contact channel.

Source: Own work

The final stage in the main research scenario was the follow-up contacts. Regardless if made by phone or with use of internet tools, they give a chance to assist customer during the offer comparison and the decision-making process, to clear up possible misunderstandings and stress the key points of the offer or alternatively to prepare a new one. But as the Fig. 4 indicates, in a struggle for easy deals, the sales persons seem to leave the customers still considering their options with their own thoughts, letting at risk all the investment of time they have made during the preceding stages of the contacts. Only $42 \%$ try to sustain dialogue and even less act proactively, e.g. exploring alternatives the customer compares. 


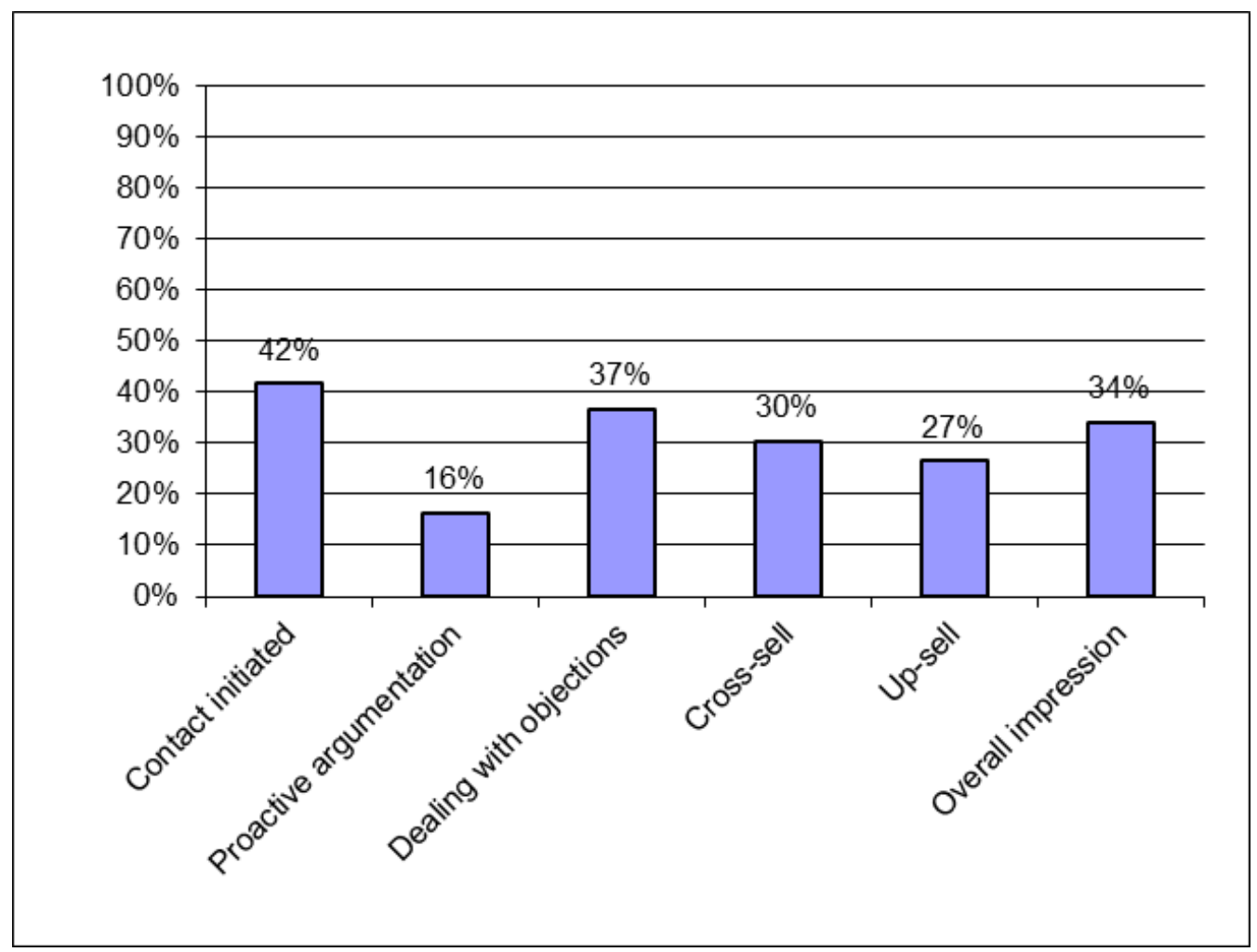

Figure 4. Opportunity management in follow-up contacts.

Source: Own work

The aggregated research results (Fig. 5) bring an image of severe problems in maintaining seamless, high quality dialogue with the customers through the different communication channels. Although the performance during the phone and personal contacts seems not to be dramatically poor, the leakages in the marketing funnel at preceding and succeeding stages of the contacts, significantly reduce the overall effectiveness of the opportunity management process at one hand and customer experience at the other, bringing losses in value creation chain of both parties.

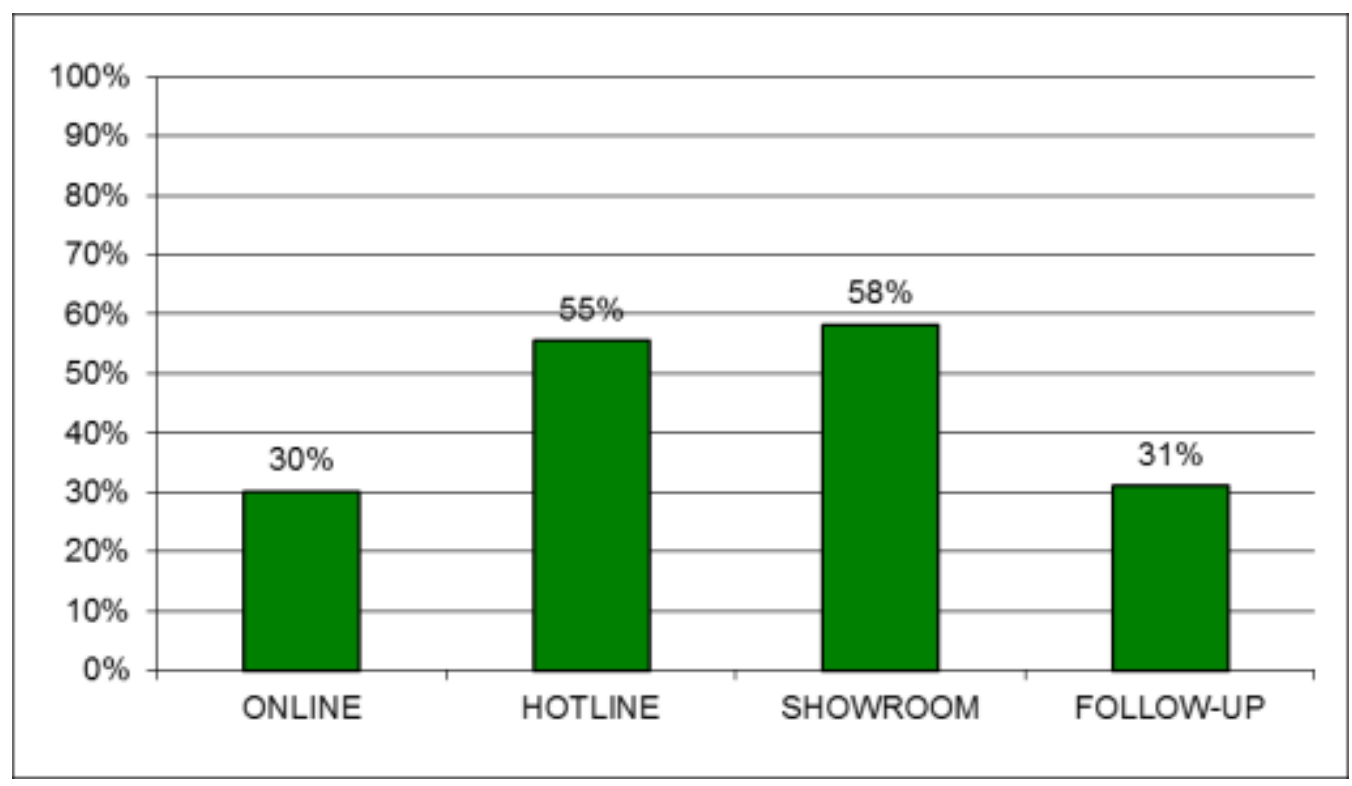

Figure 5. Opportunity management (aggregated results).

Source: Own work 
In particular, if one assumes that in contemporary market the customer will only opt for an offer if he is given an exceptional uninterrupted level of services, the theoretical waste in sales potential in the opportunity management process accounts for $97 \%$ (compound percentage of losses). While some research show only $25 \%$ of the leads in the sales pipeline are the legitimate prospective buyers (Gleanster, 2014), this cannot be an explanation for the general disinterest in taking a chance to continue the dialogue. "Brooming" is called this phenomenon, when a sales person asks a few questions looking for a fast sale and if the customer is not immediately ready to take a decision "de-qualifies" him trying his luck with the other clients (Krogue, 2014). Unfortunately such attitude is likely to affect the low priority leads as well as the "right" ones.

The housing industry seems not to be an isolated example of problems in early customer management process. There are other contractual industries, which should theoretically take an advantage of the modern strategies and IT tools supporting opportunity management, but yet - as my earlier research shows, suffer similar problems especially with mastering online channel dialogue and follow-up contacts.

The results evoked in Fig. 6 are based on the similar research methodology and were obtained in Poland in 2013 (automotive industry) and 2015 (tourist industry). Although they may differ within the same category (most evident example are the contacts in the showroom), the general trend is clear and homogenous. Industry leaders of several important contractual businesses in the biggest country of the CEE region have severe problems in unlocking the potential of the online dialogue and motivating their sales persons to assist the customers at the advanced stage of the decisionmaking process. Before I will make an attempt to explain the reasons for such a situation (see section Conclusions, recommendations and research limitations), the results of the additional stage in current research must be revealed.

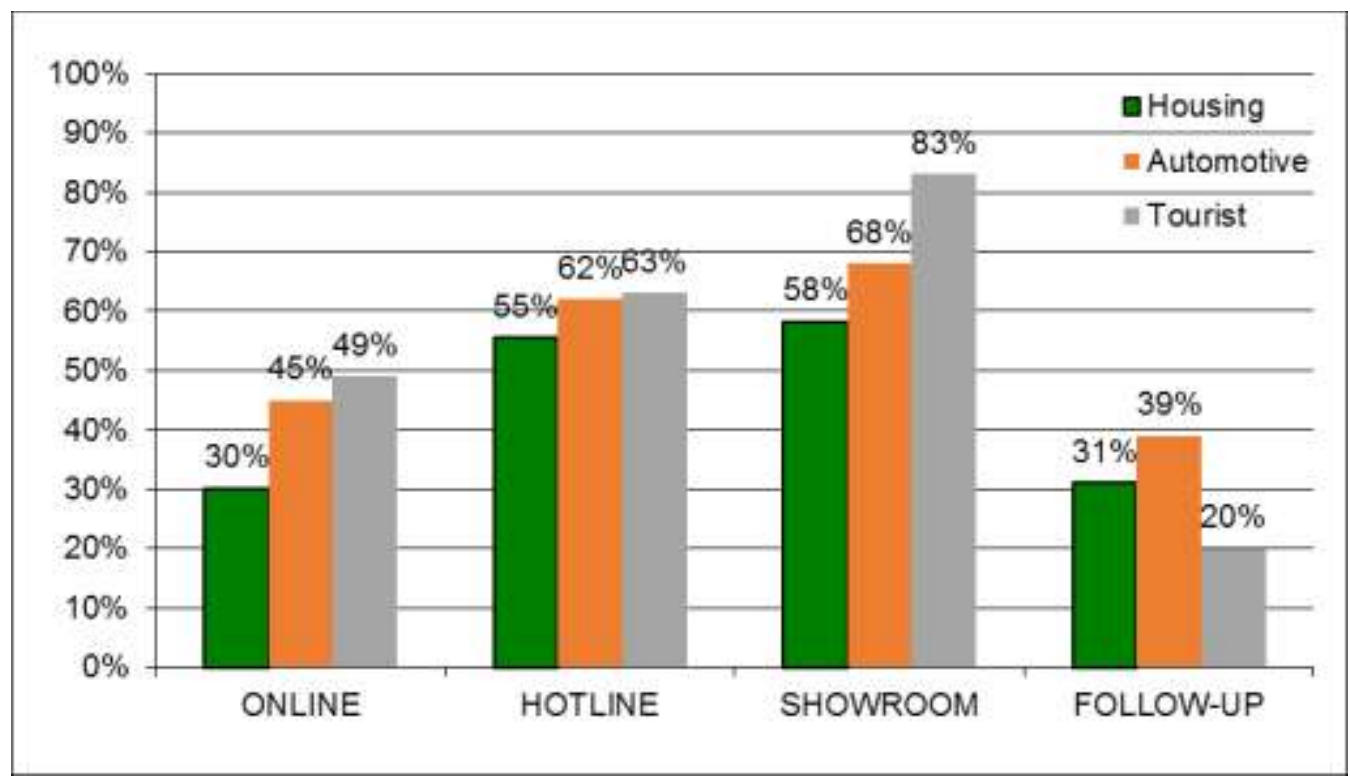

Figure 6. Opportunity management (aggregated results across three industries)

Source: housing industry: own work, automotive industry: (Deszczyński \& Mielcarek 2014, p. 46), tourist industry: (Deszczyński, 2016 a, p. 4).

The goal of the long-term lead management scenario was to investigate the ability of the companies to collect, register and process customer data not for the purpose of the immediate sale but for the future reference. It is obvious that making a memo on a sticky note card or in a calendar reminding of a contact in a couple of days is much easier than putting the same data and assigning a distant task in a CRM system. And so the hurdle at this stage of the research seems to 
be placed even higher than for mastering multichannel dialogue. After revealing the intention to take buying decision in a month, $80 \%$ of the mystery clients were asked to leave their contact data for the future reference. However, only $18 \%$ of the sales persons contacted the prospective buyers as the appointed time has come. In the light of above, almost any investment in training, marketing and the ICT is a waste of resources. It seems that the immature organizations are so heavily bound to the myopic transactional way of doing business, that they are in a position to merely utilize the sales skills of a chapman. On the contrary only companies which can simultaneously manage employees, processes and the ICT are capable in exploiting the potential of "who - what - when" information and contact the potential customers with the right offer at the moment of their readiness to buy (Deszczyński, 2016 b).

\section{CONCLUSIONS, RECOMMENDATIONS AND RESEARCH LIMITATIONS}

The research outcomes in the housing industry presented in this article as well as the evoked results of similar research conducted in the automotive and tourist industry in Poland, clearly indicate a major problem of business underperformance. Heavy losses in managing the leads indicate the corporate inability to sustain a dialogue with the customers and as such cannot be treated only as some shameful but limited inefficiencies affecting marketing or sales. The opportunity management is not only the gateway for a successful relationship, but it also directly affects the ability to hit the sales targets. It deals with the customers who currently possess propensity to buy, not in a distant time. Hence performance in managing the online leads may reflect the corporate proficiency in the other fields of the customer service. If it is managed poorly at the point so close to sales, it will be probably done even worse once the goals are more intangible, e.g. in complaint management or in other after-sales activities.

In this context ineffectiveness in opportunity management can be considered as one of the indicators of the overall corporate relationship management immaturity (Deszczyński, 2016 b), as the companies are even not capable to train and motivate their own front office employees to take the chance on sales activities, which should be (at least in the theory) beneficial for themselves. Hence it seems once again that the relationship management programs are much more peopleintense ventures than any other business activity (Baran \& Galka, 2013; Payne \& Frow 2013). In the end it is not the company that engages the customers in a dialogue, but the employees. Mastering such process of many actors with crossborder organizational responsibility and a lot of intangible phenomena like trust and commitment (Doney \& Cannon 1997; Morgan \& Hunt 1994) implies not only to acknowledge empowered customers but also empowered employees (Deszczyński 2016c; Smith 2006; Johnson \& Redmond 1998). In addition, the organizational infrastructure needs to be adjusted to support this dialogue and to make it more profitable (Mruk \& Stępien, 2007). Hence, although many tactical answers can partly explain underperformance in opportunity management, e.g. inadequate number of front-office personnel or mismanagement in coordination of various front office teams, the roots of this problem seam to lay at the CXOs' level. It is the top management's responsibility to make a company fit for the effective pursue of customer relationship management, which requires coordination of the three dimensions: the relationship marketing strategy, the ICT tools and change management focused on own people and processes (Deszczyński, 2014a, p. 542).

With regard to the research limitations the above discussion and conclusions are primary relevant to one country and three industries only. However given the fact that Poland is an open economy, there exist a certain degree of probability, that the results would be similar in the other industries and territories. If so, the overall corporate relationship management immaturity, would be at least a partial answer to high CRM implementation failure rates, which have been oscillating around $70 \%$ since they were reported for the first time by Gartner Institute in 2001 (Deszczyński, 2014 b, p. 29). Even without footing of additional research, it seems that opportunity management should be treated very seriously by any business. Progress in this area can bring substantial improvements in customer and employee satisfaction and quickwins enhancing customer relationship management implementation projects. 


\section{ACKNOWEDGEMENT}

This article was prepared as a result of research project 2015/19/D/HS4/01956 funded by the Polish National Science Centre.

\section{REFERENCES}

Baran, R.J., Galka, R.J., 2013, CRM, The Foundation of Contemporary Marketing Strategy, Routledge, New York.

Bueren, A., Schierholz, R., Kolbe, L. i Brenner, W. (2005). Improving Performance of CustomerProcesses with Knowledge Management. Business Process Management Journal, 11 (5).

Domiporta, 2016, Retrieved October 08, 2016, from

http://www .domiporta.pl/nowe/deweloperzy/1?Lo calization $=$ wielkopolskie

Deszczyński B., 2016a, Multi-channel opportunity management. An exploratory research on the example of tourist industry, Marketing i

Zarządzanie nr 5 (46) 2016, Wydawnictwo Uniwersytetu Szczecińskiego, Szczecin.

Deszczyński B., 2016 b, The Maturity of Corporate Relationship Management, Gospodarka Narodowa, 3, /2016 (283), Rok LXXXVI/XXVII, maj-czerwiec 2016.

Deszczyński B., 2016 c, Upodmiotowienie pracowników jako element przewagi konkurencyjnej w organizacjach ukierunkowanych na zarządzanie relacjami. Studia Ekonomiczne 255, Wydawnictwo Uniwersytetu Ekonomicznego w Katowicach, Katowice.

Deszczyński B., 2014 a, Globalne strategie zarządzania relacjami z klientami[in:]: M. Gorynia, S. Rudolf (ed.), Polska w Unii Europejskiej i global nej gospodarce, Polskie Towarzystwo Ekonomiczne (PTE), Warszawa 2014.

Deszczyński B., 2014b, Zasoby relacyjne konceptualizacja pojęcia w świetle zasobowej teorii przedsiębiorstwa, Studia Oeconomica Posnaniensia, vol. 11.

Deszczyński, B., 2013, Lead management jako źródło short-term wins w procesie zarządzania relacjami z klientami, Marketing i Rynek, nr 5, Polskie Wydawnictwo Ekonomiczne (PWE), Warszawa.

Deszczyński B., 2005, Zarządzanie Relacjami z Klientami (CRM) w przedsiębiorstwie [in] :
Funkcjonowanie gospodarki rynkowej w Polsce: aspekty makro- i mikroekonomiczne, Wydawnictwo Uniwersytetu Ekonomicznego w Poznaniu, Poznań.

Deszczyński B., Mielcarek P., 2015, Nieciągłości w procesie zarządzania szansami sprzedaży w branży motoryzacyjnej, Marketing i Rynek, 2, Warszawa.

Deszczyński B., Mielcarek P., 2014, The online / offline gap in lead management process, Przegląd Organizacji, 8

Doney P.M., Cannon J.P., 1997, An Examination of Trust in Buyer-Seller Relationships, Journal of Marketing, vol. 61, no.2, April.

Gleanster Research, 2014, Retrieved July 11, 2014 from

http://www.gleanster.com/search/lead\%20manage ment.

Gordon, I.H., 2013, Managing the New Customer Relationship, Strategies to Engage the Social Customer and Build Lasting Value, Wiley \& Sons, Mississauga.

Haythronthwaite C., Bruce B.C., Andrews R., Kazmer M.M., Montague R.-A., Preston C., 2007, Theories and models of and for online learning, First Monday Vol.12, Number 8-6 August.

The Independent, 2016, Retrieved October 03, 2016, from http://www.independent.co.uk/property/howoften-do-people-move-house-8969393.html

Johnson R., Redmond D., 1998, The Art of Empowerment. The Profit and Pain of Employee Involvement, Financial Times Professional Ltd., London.

Kotarba M., 2016, New factors inducing changes in the retail banking customer relationship management (CRM) and their exploration by the Fintech industry, Foundations of Management, Vol. 8 (2016), de Gruyter open 2016.

Krogue K, (2014, Three Critical Opportunities Automobile Dealers Can't Afford to Miss in a Down Economy, Retrieved July 11, 2014 from http://www.kenkrogue.com.

Ledbetter A., Mazer J.P., 2014, Do online communication attitudes mitigate the association between Facebook use and relational interdependence? An extension of media multiplexity theory, New media \& society 2014 , 
Vol. 16(5) 806-822.

Mazur J., Zaborek P., 2014, Validating DART model, International Journal of Management and Economics (Zeszyty Naukowe KGŚ) No. 44, October-December 2014.

McGinnis, F. i McCarty, L. (1998). Strategic Account Management in the New Procurement Environment. Supply Chain Management, 3 (1).

Miesięcznik Administrator, 2014, Retrieved October 03, 2016, from

http://www .administrator24.info/artykul/id6050,j ak-czesto-zmieniamy-miejsce-zamieszkania

Morgan, R.M., Hunt, S.D., 1994, The Commitment-Trust Theory of Relationship Marketing, Journal of Marketing, vol. 58, no. 3, July.

Mruk H., Stępień B., 2007, Klient jako źródło przewagi konkurencyjnej w przedsiębiorstwie międzynarodowym - perspektywa instytucjonalna, [in:]: J. Schroeder, B. Stępień (ed.), Handel i finanse międzynarodowe w warunkach globalizacji, Wydawnictwo Akademii Ekonomicznej w Poznaniu, Poznań.

Payne, A., Frow, P., 2013, Strategic Customer Management, Integrating Relationship Marketing and CRM, Cambridge University Press.

Polińska A., Skoczeń J.M., 2014, Retrieved October 03, 2016, from

http://strefynieruchomosci.blog.pl/2014/05/08/jak -polacy-kupuja-mieszkania-i-domy-od-

dewelopera/

Prahalad C.K., Ramaswamy V., 2004, Co-creation experiences: the next practice in value creation, Journal of Interactive Marketing, volume 18, number 3, summer 2004.

Rigby, D.K. i Ledingham, D. (2004). CRM Done Right. Harvard Business Review, (November).

Salomann, H., Dous M., Kolbe, L. i Brenner, W. (2006). Advancing CRM Initiatives with Knowledge Management. Journal of Information Science and Technology, 3 (2).

Sauberlich, F., Smith, K. i Yuhn, M. (2005). Analytical Lead Management in the Aautomotive Industry. W: D, Baier, R. Decker i L. SchmidtThieme, Data Analysis and Decision Support. Berlin, Heidel berg: Springer.

Smith J., 2006, Empowerment. Jak zwiększyć zaangażowanie pracowników, Helion, Gliwice.
Wielgo M., 2015, Retrieved October 03, 2016, from http://mieszkaniowy.blox.pl/2015/05/JakPolacy-wybieraja-mieszkania.html.

\section{ABOUT THE AUTHORS}

Bartosz Deszczyński email: bartrainy@gmail.com

Dr. Bartosz Deszczyński is assistant professor of management at Poznan University of Business and Economics. He authored and co-authored more than 25 books and articles dealing with the issues of strategic management, corporate relationship management and public relations. His interests include also the theories of the company especially the Resource Based View (RBV) in context of the relationship assets. 